\title{
O modelo de crença que determina o comportamento de mulheres portadoras do vírus da imunodeficiência humana - Tipo 1
}

\author{
Elucir Gir** \\ Marcia Maria Fontão Zago*** \\ Geraldo Duarte****
}

\section{RESUMO}

O objetivo deste trabalho é construir um modelo de crenças sobre o comportamento sexual das mulheres soropositivas ao HIV-1, a partir do referencial teórico de ROSENSTOCK. A amostra constituiu-se de 14 mulheres soropositivas ao HIV-1, que souberam do diagnóstico da infecção durante o pré-natal. Para a coleta de dados, empregou-se a técnica de entrevista semi-estruturada gravada, norteada por formulário específico. A partir das falas das informantes, cinco categorias foram construídas: A) Percepção da Infecção/Doença, B) Percepção da Reação Social à Doença, C) Busca para conviver com a situação, D) Papel Social e E) Comportamento Sexual. A inter-relação entre elas permitiu a construção do

\footnotetext{
* Trabalho vencedor do Prêmio SBRASH no IV Congresso Paulista de Sexualidade Humana-SP.

** Professor Associado junto à Escola de Enfermagem de Ribeirão Preto - USP.

*** Professor Doutor junto à Escola de Enfermagem de Ribeirão Preto-USP.

***** Professor Associado junto à Faculdade de Medicina de Ribeirão Preto - USP.

Recebido em 02.03 .98

Aprovado em 12.03.98
} 
Modelo de Crenças que explica os fatores referentes ao comportamento sexual. Ficou evidente que o comportamento sexual é influenciado pelos determinantes mostrados nas categorias e que há necessidade de intervenção psicosexual pelos profissionais de saúde.

UNITERMOS: HIV/Aids; sexualidade; mulheres.

\section{SUMMARY}

This investigation was carried in order to construct a health model about the sexual behavior of HIV-1 infected women, based on Rosenstock theorethical framework. The sample was composed by 14 HIV-1 seropositive women, that knew about their clinical condition, specially during the prenatal period. To collect the data we used the semistructured and recorded interview, based on a specific formulary. Based on the woman speech, five categories were ellaborated; A. Perception of Infection/Disease, B. Perception of Social Reaction to the Disease, C. Searches to live with the situation, D. Social Role, E. Sexual Behavior. Each category was composed by their subcategories. The interrelation among them permitted the construction of the belief model that explains factors concerning the sexual behavior. It was evident that sexual behavior is influenced by features shown at categories and subcategories. There is urgent need of psycosexual intervention and the health professionals need to work effectively the sexual dimension.

UNITERMS: HIV/Aids; sexuality; women.

\section{INTRODUÇÃO}

A Aids é considerada um dos sérios problemas de saúde pública difundidos no mundo que não encontra precedentes na história.

Estima-se em 7 milhões o número atual de pessoas infectadas, devendo atingir pelo menos 40 milhões no ano 2000 (WHO, 1995). No Brasil, o número de casos de Aids registrados totaliza 116.389 no período compreendido entre 1980 e agosto de 1997. Vale ressaltar que a maioria é do Estado de São Paulo, e a cidade de Ribeirão Preto ocupa a incômoda e preocupante posição de destacar-se entre as cinco cidades com maior incidência do país (BRASIL, M. S., 1997). A subnotificação de casos é real, entretanto, a situação no Brasil não é diferente das outras áreas geográficas do globo. 
Hoje, dezessete anos após o aparecimento do Vírus da Imunodeficiência Humana (HIV), tem-se um quadro claro das ameaças que esse agente impõe à saúde física e mental. Os índices de prevalência e incidência continuam crescendo de maneira devastadora. Os danos e as conseqüências ocasionados aos contaminados transcendem o biológico e provocam danos sociais que repercutem nas famílias.

Ao contrário do que se pensou no início da década de 80, a infecção pelo HIV não se limita à identidade sexual mas aos comportamentos adotados. Historicamente, iniciou-se entre homossexuais masculinos e, nos últimos anos, é o heterossexual quem lidera as estatísticas. Em termos de gênero sexual, em 1983 o número de casos no Brasil correspondia à proporção de 40 indivíduos do sexo masculino para um do sexo feminino. Atualmente esta proporção vem se mantendo em 3:1 desde 1994.

HOLMBERG (1997) menciona que o risco está subordinado à fatores comportamentais e biológicos. Dentre os comportamentais, logicamente que a participação de um parceiro infectado é essencial, além dos tipos de práticas sexuais e a parceria sexual múltipla, Ser parceiro receptivo constitui um risco maior para concretizar a infecção. Outro determinante do comportamento sexual inseguro é o uso de substâncias que provocam alterações na condição mental e, por sua vez, influenciam a tomada de decisões (MOLGAARD et al., 1988). O uso abusivo de drogas ilícitas como o álcool, o "crack", a cocaína configuram-se como marcadores ou co-fatores que indiretamente acabam impondo riscos sexuais, visto que os seus adeptos, sob efeito dos mesmos, muitas vezes passam a não exercer controle sobre o seu comportamento.

Quanto aos fatores biológicos, destacam-se as condições que suscitam rupturas ou abrasões da mucosa genital, como doença sexualmente transmissível (DST), introdução de objetos fálicos, rituais de escarificação e infibulação, o estágio da infecção pelo HIV, a virulência, a infectividade.

A transmissão heterossexual pode ocorrer bidirecionalmente, isto é, a partir da mulher infectada para o homem não infectado, ou do homem infectado para a mulher não contaminada. A literatura indica que esta última condição ocorre mais efetivamente, por ser receptiva no coito penetrativo, e pelo fato do vírus apresentar-se em quantidade significativamente maior no sêmen, quando comparado a outros fluidos corporais (OSMOND, 1990).

Assim, a mulher é a grande vítima na transmissão heterossexual. Além do mais, tem-se o problema adicional da transmissão vertical do 
HIV-1 que representa a principal forma de disseminação desse vírus na população pediátrica (van VLIET \& ROOSMALEN, 1997), cujos casos estão em franca ascensão. A transmissão do vírus da mãe para a criança se efetiva em 13 a 48\% (MERTENS \& PIOT, 1997). A profilaxia com anti-retroviral tem mostrado resultados plausíveis para a criança, entretanto o problema da possível orfandade não é descartado.

A infecção pelo HIV na mulher cresce rapidamente e representa um problema de magnitude irrefutável para a humanidade, Ao binômio HIV/Aids e MULHER vincula-se o processo da sexualidade, tornando imperiosa a necessidade de se compreender o comportamento sexual humano, para se compreender o indivíduo, enquanto ser sexual e sexuado.

Frente a problemática HIV/Aids, mulher e sexualidade, considerase que a mulher pode se vitimizar principalmente pelo comportamento sexual desprotegido ou inseguro, tornando-se infectada pelo HIV-1 e a partir daí, vivenciar todos os sérios problemas que a infecção confere.

Preocupados com essa situação, este estudo foi elaborado com o objetivo de construir o modelo de crenças sobre o comportamento sexual das mulheres soropositivas ao HIV-1.

\section{METODOLOGIA}

Este estudo é parte de um projeto maior que trata da sexualidade da mulher portadora de HIV-1 (GIR, 1997). Para a seleção das participantes, consideramos os seguintes critérios de inclusão: ser mulher soropositiva ao HIV-1, ter tido pelo menos uma de suas gestações resolvidas no período compreendido entre junho de 1991 e janeiro de 1997 no Hospital das Clínicas da Faculdade de Medicina de Ribeirão Preto - USP (HCFMRP-USP); ter tido sua gestação resultado em feto vivo, ter comparecido aos retornos médicos junto ao Ambulatório de Moléstias Infecto-Contagiosas (AMIGO), no período entre janeiro de 1996 e julho de 1997; ter tido o seu diagnóstico de infecção pelo HIV-1 antes ou durante o pré-natal, ou por ocasião do parto; ter conhecimento da sua condição sorológica há pelo menos 6 meses; ter aquiescido em participar da pesquisa; ter apresentado espontaneidade e clareza durante a entrevista; apresentar curso de vida interessante à temática. Participaram do estudo 14 mulheres, de uma amostra de 50 participantes do AMIGO. Sendo uma amostra intencional, foi considerada a saturação teórica das informações. 
A coleta de dados foi norteada pelas questões:

1. Fale sobre a maneira como você se contaminou pelo HIV.

2. O que significa/significou estar grávida e saber que está/estava contaminada pelo HIV?

3. Descreva as mudanças que ocorreram na sua vida depois que soube que você tinha o HIV.

4. Descreva a sua reação quando soube que estava infectada pelo HIV.

5. Descreva como você se sente hoje sendo portadora do HIV.

6. Descreva a sua vida sexual antes de saber que estava com o HIV.

7. Descreva a sua vida sexual depois de saber que estava infectada. E hoje?

Para a coleta de dados empregamos a técnica de entrevista semiestruturada gravada, norteada pelas questões acima descrita. Como etapa antecedente, procedemos à leitura do prontuário da paciente, bem como a sua retomada posterior para certificar certos dados que eram possíveis de ser encontrados no prontuário.

As entrevistas foram realizadas em uma das salas do ambulatório, no dia do retorno médico agendado, antes ou após a consulta médica; cada entrevista durou de 30 a 90 minutos. Foram realizadas mais de uma entrevista com cada participante visando esclarecer dúvidas quanto aos dados não totalmente compreendidos na entrevista anterior, bem como para acrescentar informações recentes.

A coleta de dados ocorreu no período de janeiro de 1996 a julho de 1997.

No encontro com cada paciente, explicávamos a ela o objetivo do trabalho e solicitava-lhe aquiescência para entrevistá-la e gravar a entrevista, além de assegurar-lhe o anonimato.

Após cada encontro, as entrevistas gravadas eram transcritas. Visando assegurar a fidedignidade da transcrição e digitação, procedemos à checagem das mesmas, conferindo a transcrição com a gravação.

Para a análise dos dados utilizamos a estratégia da Análise de Conteúdo, preconizada por BARDIN (1977). Esse autor define tal método como um conjunto de técnicas de análise das comunicações visando obter, por procedimentos sistemáticos e objetivos de descrição do conteúdo das mensagens, indicadores (qualitativos ou não) que permitam a inferência de conhecimentos relativos às condições de produção/recepção destas mensagens. Esse método compõe-se das fases de pré-análise, exploração dos dados e tratamento e interpretação dos resultados. Na pré-análise, pro- 
cedemos à leitura flutuante, superficial dos depoimentos. Após, efetuavámos uma leitura mais cautelosa e aprofundada onde selecionávamos as entrevistas que se enquadravam nos critérios definidos, procurando identificar, sobretudo, os conteúdos recorrentes e as contradições que espontaneamente emergiam.

A seguir realizamos a exploração do material, selecionando as unidades de análise contidas em cada caso, atribuindo-lhes codificações. Os códigos foram definidos considerando-se a temática e o referencial teórico-metodológico.

$\mathrm{Na}$ etapa seguinte construímos as categorias de significados e das dimensões do comportamento sexual. A categorização é um procedimento de separação de elementos componentes de um todo, por diferenciação e por reagrupamento, mediante os critérios estabelecidos. As categorias são classes que reúnem um conjunto de elementos (unidades de análise) sob um título genérico. Esse agrupamento é feito considerando-se os aspectos comuns dos elementos.

Nessa investigação utilizamos categorias semânticas ou temáticas, onde as falas compuseram cada categoria, apresentavam significados semelhantes, porém com conotações distintas, complementares ou até mesmo contraditórias. O nome atribuído a cada categoria foi definido no término da etapa.

Uma vez descritas as categorias, estas foram validadas por dois pesquisadores especialistas no método qualitativo, encontrando-se concordância entre ambos.

A última etapa consistiu na construção do Modelo de Crenças que determina o comportamento sexual de mulheres portadoras do vírus HIV tipo 1. O Modelo possibilita apreender as crenças das mulheres que foram imperiosas para o infectar-se por esse vírus, bem como para o atual comportamento sexual.

As mulheres, sujeitas desta investigação, eram em sua maioria amasiadas, com faixa etária média de 25,1 anos, com escolaridade primária predominante e residentes em Ribeirão Preto, estão na fase clínica assintomática de infecção pelo HIV-1.

\section{APRESENTAÇÃO E DISCUSSÃO DOS RESULTADOS}

A maioria das mulheres souberam do seu diagnóstico de infecção durante a gravidez ou por ocasião do parto. 
No serviço onde o estudo foi desenvolvido, as mulheres grávidas se submetem a este teste mediante consentimento, o que vem a ser a sorologia permitida.

Depois de saberem do diagnóstico de sua soropositividade, certas mulheres informaram que se mantiveram apenas com o parceiro vigente na ocasião e outras afirmaram ter tido outros parceiros.

As mulheres referiram não apresentar nenhum fator de risco intrínseco a elas para terem contraído o HIV-1. O fator de risco foi extrínseco, representado pelo seu parceiro sexual.

Após a análise de conteúdo das falas das pacientes, identificamos cinco categorias relacionadas as dimensões do comportamento sexual. As falas das pacientes serão apresentadas com nomes fictícios.

\section{- Categoria A: PERCEPÇÃO DA INFECÇÃO/DOENÇA}

Essa categoria revela o conhecimento das mulheres sobre a transmissão e prevenção do HIV-1, a reação ao diagnóstico, a subestimação a infecção/doença e a morte anunciada.

Há informantes que manifestaram ter conhecimento sobre a infecção antes de saberem que estavam contaminadas, como se observa nas falas a seguir:

"Eu sabia sim. Mas não procurava informações mais profundas. Eu sabia que era uma doença contagiosa, perigosa, mas na época era muito divulgado como doença de drogado e homossexual. " (Maria)

"Só sabia que pegava por relação sexual e transfusão de sangue. "(Inês)

Algumas pacientes têm noção de como se contaminaram e, dentro da atribuição causal-sexo, elas identificam como fator de risco, o comportamento do parceiro.

“Ah, eи peguei o HIV dele, no sexo. Porque... ele põe droga na veia, ele fazia tudo isso... e eu não sabia.” (Célia)

"Eu acho que dele não peguei não! Isso daí não! Eu acho que não foi dele porque ele morava em fazenda, sabe, desses mocinhos.., não sabia do mundo, de nada. Meu marido, tenho certeza que foi dele!" (Bete) 
Algumas mulheres revelam a preocupação com a doença e buscam esclarecer suas dúvidas. Por outro lado, a desinformação sobre a prevenção, antes de conhecer o diagnóstico, é verbalizada pela maioria:

"Antes de pegar o vírus eu não tinha nem idéia, nem imaginava. É... a gente pensa que o que acontece com as pessoas, não vai acontecer com a gente. "(Toninha)

As informantes atribuem a responsabilidade pela sua infecção à via sexual. A probabilidade de uma mulher não infectada adquirir o HIV-1 por contato através de prática vaginal a partir de um homem, é menor do que $0,2 \%$.

A probabilidade estatisticamente baixa, da transmissão ocorrer em contato homo ou heterossexual, por ato sexual único permanece não definida. Há parceiros de infectados que continuam soronegativos após centenas de contatos sexuais, ao passo que outros se contaminaram em poucos contatos, ou até mesmo em contato único (CLUMECK et al., 1989; HOLMBERG et al, 1989).

Diferentes reações foram manifestadas pelas mulheres, ao serem comunicadas sobre o resultado positivo do teste:

"Ah, eu chorei, nossa, mas eu chorei tanto! Chorei tudo o que tinha que chorar. Me senti sozinha e nunca aceitei sabe, desde quando... eu nunca aceitei! Eu nunca aceitei ter este vírus. “ (Toninha)

“Ah, eu fiquei triste, chorei, pensava até em me matar. " (Bete)

As informantes expressam revolta, nervosismo, negação do diagnóstico, tristeza, pensamentos suicídas, em suas falas. CAPALDINI (1997) menciona que os portadores de HIV são confrontados com múltiplos estressores psicossociais, em todas as fases da infecção, com intensidades variadas.

Quanto a revelação do diagnóstico, identificamos dois aspectos: o da omissão e o da revelação. As informantes descrevem a omissão do diagnóstico, por parte dos parceiros, e a omissão delas em relação a eles e aos outros.

"Ele falou que ficou com medo. Então, eu não senti raiva dele, eu senti dó! Então, eu comecei a cuidar mais dele e de mim também. “(Inês) 
"Estou namorando, mas não falei para ele que tenho o vírus, porque eu não sei o que ele faz comigo. Ele pode me abandonar, me matar... tenho medo da reação dele!" (Joana)

A subestimação da infecção/doença emergiu com frequiência, nas falas das informantes:

“...isso não me traz preocupação nenhuma... “(Célia)
“...pensava que era uma doença fora do meu caderno. “(Marilu)

JOFFE (1995) ao investigar as representações sociais da Aids entre 60 jovens sul africanos e britânicos, encontrou as representações: a "Doença do Outro", "Eu Não", "Não o Meu Grupo". Ressaltamos que a ilusão da invulnerabilidade à doença se aplica a uma variedade de outros riscos à saúde e eventos, tais como: doenças crônicas, acidentes e crimes. Assim, percebe-se com muita evidência que as informantes subestimam o potencial da sua infecção pelo HIV-1, em relação aos danos para si própria, como para os seus parceiros.

Porém, há uma outra conotação, em relação à percepção da doença: o significado da morte. anunciada:

"Sabendo que sou uma pessoa que tem o HIV eu não sou uma pessoa tranqüila. Eu sinto um medo enorme!" (Carla)

"Ah, eu já pensei que o mundo para mim estivesse acabando. Achei que ia morrer daqui a uma semana. Veio um monte de coisa tia minha cabeça. “(Antonia)

Percebe-se que a idéia de fim, de morte, permeia diferentes momentos e situações na vida das mulheres portadoras de HIV-1. O estigma de doença incurável e fatal contribui para a acentuação deste significado. De maneira semelhante, HANAN (1994) destaca que os portadores de Aids revelaram que é difícil aceitar a sua finitude porque a sociedade delega a morte aos velhos. A partir do momento em que as pessoas tomam conhecimento do diagnóstico de uma doença incurável e fatal, mesmo estando no estado assintomático, a idéia de finitude se manifesta na existencialidade do indivíduo de forma esmagadora e a pessoa vivencia antagonismos diversos.

Por esta categoria de dados, apreendemos que o desconhecimento e as crenças sobre a doença, fazem com que as mulheres pratiquem comportamentos sexuais inseguros. Grande parte das informantes soube do seu diagnostico por acaso e a notícia de ser portadora do HIV gerou conflitos 
internos diversos,entre eles, a percepção da finitude. Pela característica de ser fatal, o diagnóstico nem sempre é revelado no sentido de se poupar das discriminações, quando é mais seguro revelar o diagnóstico da doença para a família.

\section{- Categoria B: PERCEPÇÃO DA REAÇÃO SOCIAL À INFECÇÃO/ DOENÇA}

Essa categoria abrange dois aspectos: o preconceito com a infecção/doença e a solidariedade dos outros.

Alguns aspectos do preconceito e estigma da doença já foram apresentados na categoria anterior. Neste momento, outros aspectos ou dimensões surgiram. Pelas falas, o preconceito leva a não divulgação do diagnóstico a outros contextos, como no trabalho, relação a outras doenças e consigo mesma, por temer as consequiências da rejeição e desemprego.

"Trabalho numa casa de família. Se soubessem, en estaria sem o serviço. " (Marilu)

"Ah, bastante gente já falou na minha cara, jogaram para mim... Sabe, xinga, fala que eu sou aidética... "(Carla)

Dialéticamente, o preconceito caminha junto com a solidariedade, com o apoio da família e amigos:

"Mudou com a minha família. Minhas irmãs tomam mais cuidado comigo... " (Bia)

O apoio e a solidariedade são atitudes sociais positivas que favorecem a condição de vida em vários níveis: biológico, emocional, imunológico a mental das informantes. Entretanto, o preconceito é muito mais freqüente do que a solidariedade e se difunde com muito mais rapidez.;

No início da década de 80, quando as formas de transmissão não estavam claramente definidas, os portadores se submeteram à situações de discriminação e preconceito. Os amigos, colegas, familiares evitavam a proximidade; não adentravam o quarto do hospital, ficando na porta; havia rejeição, abandono, segregação. A outra vertente a ser considerada é que muitos profissionais da saúde se contaminaram com este medo, adotando atitudes indesejáveis tais como a recusa ou omissão da assistência ao portador de HIV. 


\section{- Categoria C: BUSCA PARA CONVIVER COM A SITUAÇÃo}

Nesta categoria apreendemos a importância da fé religiosa para o enfrentamento da realidade. A fé religiosa é apresentada como um mecanismo para superar a crise da confirmação do resultado e da infecção, e para o enfrentamento após a constatação da negativação do exame:

“Acho que a religião ajuda quando estamos doentes. Dá mais força para pessoa enfrentar o problema. Em primeiro lugar as pessoas da igreja dão apoio e este faz muito bem, né?” (Cida) "Vou na igreja, creio muito nesse Deus, que há de me dar muita vida ainda para cuidar dos filhos que eu tenho. Eu creio que ainda vou me curar... essa é a minha fé... “ (Marilu)

Há informantes que buscaram a fé em diferentes filosofias religiosas, outras mostraram neutralidade na fé religiosa:

“Ah, antes... eu era crente, depois, parei de ir na igreja. Agora eu não vou para lugar nenhum." (Antonia)

“... a gente faz a corrente, Jesus cura! Aí, acontece que vem o acomodamento, sabe, entende? Eé por isso que en acredito que eu estou curada. Eu acredito que Jesus me curou... eи creio que estou curada. "(Toninha)

Para REED (1987), as religiões fornecem estruturas para o desenvolvimento do sistema de crenças, de valores e de rituais. A espiritualidade integra e transcende a natureza biológica e psicossocial de todo indivíduo. As pessoas precisam assegurar o valor da vida para acreditar que ela tem significado e sentirem-se necessárias, amadas e com esperança. Assim, a religião e a espiritualidade oferecem explicações para os eventos, favorecendo a qualidade de vida.

O segundo aspecto desta categoria refere-se ao enfrentamento da realidade. Pelas falas, percebemos que o convívio com a realidade desvenda sentimentos e reações nas pessoas:

"Ah, hoje eu me sinto melhor, sabe? Mas, assim mesmo, eu fico bastante triste, parece que me dá uma angústia de vez em quando. “(Antonia)

"Eu não sou aquela que fica assim: não, eu tenho aquela doença! E fica martelando aquilo na cabeça, né? Eu sei que tenho essa doença. " (Lúcia) 
O enfrentamento à confirmação do diagnóstico e da sua fatalidade provocam alterações no estilo de vida das mulheres. Estas mudanças ocorrem no relacionamento sexual, afetivo e social. Para algumas informantes, o enfrentamento enfatiza à valorização a vida:

"Antes eu não dava valor à vida! Agora não, tudo o que eu fapo, eu faço com gosto. " (Cida)

“...Penso também: Ontem foi mais um dia que vivi! Então, dou aquela valorização a vida. " (Inês)

As estratégias de enfrentamento podem gerar sentimento de culpa pela doença, expectativas e preocupações pelo futuro:

"Ah, minha vida mudou e muito. Muita tristeza! Toda vez que você escuta comentário que fulano morreu de Aids, ofulano tem o virus, esse tipo de coisa me chateia, sabe?" (Marilu)

"Agora eu não faço mais planos, sabe? É assim, o hoje, eu só vivo o hoje! $O$ amanhã sem expectativas. Eu não faço mais planos para amanhã. “ (Maria)

Entre as estratégias de enfrentamento à doença, o lazer assume diferentes formas:

"Para distrair vou a igreja, sabe? Antes de ter o HIV eu vivia em barzinho, a gente ia na discoteca, ia em festinha de aniversário, dançava... “ (Toninha)

"Divertir.. a única diversão minha é que eu levanto cedo e vou para o serviço e depois vou para casa, não tenho diversão... “ (Célia)

O enfrentamento da doença também provoca alterações no comportamento sexual, tanto na fase assintomática como sintomática dos parceiros:

“A parte sexual... eи acho que alterou sim, que perdeu um pouco o clima, né!” (Inês)

"Tenho menos prazer. Chego a ter orgasmo às vezes. O número de relações também diminui. “ (Elza)

"A vontade de sexo diminuiu... diminuiu a vontade de ter relações... “(Bia) 
A valorização no trabalho foi relatada como uma forma de enfrentamento a tem diferentes implicações:

“Agora não trabalho mais em boate, trabalho numa lavanderia.

"(Carla)

"É de vez em quando eu faço uma faxina, né? O HIV só me deu mais força de vontade de viver e de trabalhar. “(Fátima)

Na busca para conviver com a situação, os mecanismos de enfrentamento das mulheres, é permeado por sentimentos contraditórios pois, ao mesmo tempo em que elas vivem momentos de esperança, de superação de problemas, vêem um amanhã incerto. Entretanto, a expectativa pela cura, a superação dos preconceitos e da culpa, são expressos de maneira mais cautelosa e tímida. De qualquer modo, as mulheres buscam "algo" em que se apoiar para enfrentar a realidade da doença e do prognóstico.

De acordo com KNAUTH (1995), a trajetória social das mulheres contaminadas pelo HIV-1, é marcada pela decadência da situação econômica. Quanto ao trabalho, refere que poucas mulheres continuam a exercer atividade remunerada sistemática, após saberem do seu diagnóstico.

KNAUTH (1995) refere que, para outras doenças, a suspensão das atividades rotineiras e de trabalho é o principal identificador da condição de doente. Para a Aids, o significado é diferente, a adoção de cuidados especiais visam à prevenção de sinais da doença, visto que o trabalho é percebido como fonte potencial para incômodos e cansaço.

$\mathrm{Na}$ presente investigação, encontramos significados diferentes quanto aos obstáculos enfrentados pelas mulheres, por ocasião da manutenção e busca de trabalho, porém, o que vale ser destacado é a valorização positiva do trabalho que lhes confere "força para viver".

\section{- Categoria D: PAPEL SOCIAL}

As dimensões do papel social da mulher envolvem a responsabilidade com a não contaminação do parceiro, a valorização do papel social materno e a sua identidade social e cultural como ser sexual.

A responsabilidade para com o parceiro, revelada nos dados, relaciona-se com o desempenho de comportamentos preventivos, com a preocupação de não ameaçar, contaminar o parceiro:

"Quando eu tinha relação com ele, sem camisinha, não pensava muito não! Agora, o juízo está batendo mais, né? Responsabilidade!" (Lúcia) 
"Agora ele aceita camisinha. Aceita porque eu falei para ele que se ele não usasse, eu preferia largar dele. Aí ele disse que gosta de mim, que não queria largar e que ia usar!" (Lúcia)

O papel sócio-cultural de ser mãe é destacado em diferentes aspectos, tanto na gravidez como após:

"Já sabia que tinha o vírus. Eu engravidei porque eu tinha vontade de ser mãe... eu não tenho medo dessa doença! Aí eu peguei, engravidei porque eu queria ser mãe. O desejo de ser mãe era mais forte. "(Célia)

Para algumas mulheres, o engravidar mesmo sabendo que é soropositiva ao HIV, gera preocupação durante a gravidez que só é minimizada com o nascimento da criança.

"Quando fez o teste estava grávida... Eu fiquei pensando no nenê, falei: ai, meu Deus, mais uma criança!” (Joana)

"Quando figuei sabendo que meu marido estava contaminado, no outro dia já faz o exame e deu. Eu pensava muito no nenê! Eu fiquei muito traumatizada!” (Elza)

Por outro lado, algumas mulheres soropositivas quando prevêem a possibilidade de estar grávidas, manifestam rejeição e desejo de submeter-se ao aborto provocado como uma alternativa solucionadora:

"Se eu estiver grávida, eu sei que é crime, mas eu vou tentar tirar!" (Bia)

"É muito triste estar grávida sabendo que você tem o vírus! Não tem jeito da gente tirar? Porque não é da minha vontade, não é do meu agrado. “(Marilu)

Mas a cultura da vocação materna, na mulher, pode ser uma estratégia de enfrentamento para ela lidar com a situação:

"Ah, eи entrei em choque, eи fiquei muito desesperada, muito triste! Aí, o que me deu força foi a gravidez. Deus dá força e tive bastante apoio da família, também. “(Elza)

"Meu filho é muito inteligente e me dá força!... Porque eu vou viver a minha vida com meu filho, até o dia que eu for embora. “(Bete) 
O período de espera pelo resultado do exame sorológico do filho, gera expectativas e esperanças de que os anticorpos maternos sejam eliminados por ocasião do primeiro ano de vida:

"Ele vai fazer oito meses (o filho) e o resultado, por enquanto, está dando positivo. Mas, eu acho que vai negativar porque está diminuindo, sabe, ele é bem saudável!" (Inês)

Alguns pesquisadores têm tentado elucidar se a gestação acelera a progressão da infecção pelo HIV. DUARTE (1993), estudando a infecção pelo HIV-1 durante o ciclo grávido puerperal em mulheres brasileiras soropositivas de nível sócio-econômico baixo, detectou nítido comprometimento do prognóstico da gestação, que se acentua com a evolução da infecção e se projeta consequências como abortamentos, natimortos, prematuridade, baixo peso ao nascer, retardo de crescimento intra-ulterino e hipóxia neo-natal. O estudo de HOCKE (1995) não revelou associação entre gravidez e progresso da infecção assintomática pelo HIV, principalmente em países industrializados.

É importante destacar que a soropositividade nas mães, acarreta uma grande preocupação na sociedade devido ao aumento da possível orfandade, independente da condição sorológica das crianças.

$\mathrm{O}$ último aspecto a ser apresentado nesta categoria refere-se à identidade sócio-cultural da mulher enquanto ser sexual e que tem um papel importante na manutenção do relacionamento afetivo com o parceiro:

"Ah, acho que transar é um meio de satisfazer um ao outro, sei lá!” (Marilu)

"A relação sexual... as pessoas deveriam levar com seriedade, com amor. Para algumas mulheres... é uma forma de ganhar dinheiro, para outras, é uma forma de amor. Acho que a mulher vive sem transar e o homem não!” (Elza)

Nesta categoria sobre o papel sócio-cultural da mulher, diferentes significados são apresentadas pelas informantes: a preocupação em não contaminar o parceiro; a subestimação à doença levando-as a decidirem-se por "correr o risco"; a relação afetiva e sexual com o companheiro; e as diferentes finalidades e motivações para o sexo. 


\section{- Categoria E: COMPORTAMENTO SEXUAL}

Nesta categoria os dados mostram que algumas informantes têm conhecimento sobre a prevenção da contaminação e tentam diferentes estratégias com os seus parceiros, para convencê-los a utilizar o condom:

"Agora, no momento, eu estou com um rapaz que não sabe do problema. Só que todos os cuidados eu tomo. Em vez de uma camisinha eu estou usando duas. " (Maria)

"Depois que eu soube, aí eu passei a usar." (Marilu)

Quanto ao sexo inseguro, o desconhecimento sobre os recursos e métodos preventivos da contaminação e as crenças sobre estes, são as justificativas para tal comportamento:

"Com o primeiro e o segundo parceiro, eu nunca usei camisinha. Com os outros eu usava, eu uso! Só com o último que não!” (Bia)

"Eu acho que a camisinha não vai resolver o problema, porque isso é uma coisa da pessoa, não são todos que vão usar camisinha... Nunca nenhum companheiro meu usou camisinha. “ (Toninha)

A não aceitação do condom pelo parceiro e pela própria mulher foi bastante ressaltada:

"Sem camisinha, porque ele não aceita camisinha. O médico já conversou com ele, disse que é importante, que ele pode pegar $o$ vírus também, que ele pode adquirir a doença e não adiantou.

“( Lúcia)

"Eu acho horrivel usar camisinha!” (Bia)

As crenças negativas atribuídas ao uso do condom já foram investigadas por diversos autores que concluíram que elas acabam determinando o desuso ou o uso incorreto do condom. Sendo assim, compete à mulher lançar mão de artimanhas de sedução, erotizando o uso do condom e, acima de mais nada, acreditar na necessidade do condom.

Pelas falas, evidenciou-se que o condom passou a ser utilizado na relação sexual de algumas destas mulheres, após elas saberem da sua soropositividade ao HIV-1. Revela-se também, a subestimação do homem acerca da infecção e a importância da mulher ser assertiva ao impor o uso do condom. 
O sexo inseguro é uma conseqüência dos valores negativos atribuídos, pelo homem e pela mulher, ao uso do condom, da subestimação do homem sobre a infecção e da passividade da mulher em acatar as práticas sexuais desprotegidas, ditadas pelo homem. Outros fatores impeditivos explícitos nas falas são a fé religiosa, o papel de mãe e a subestimação à vulnerabilidade.

Historicamente, o uso de condons se associava à prostituição, a relações extraconjugais, o que acarretava uma reputação negativa ao usuário (SHERRIS et al., 1983). Atualmente, é ainda expressivo o número de atribuições negativas a que acabam por embasar o uso assistemático e incorreto do mesmo. Destacam-se, dentre outras, a crença da redução da sensibilidade durante o coito, diminuindo o prazer sexual, a não aceitação pelo parceiro ou ofensa ao mesmo, a percepção errônea e subestimada sobre o risco de infecção, a crença de que é um método não natural a que confere embaraço no uso, que causa desconforto e desconfiança, a idéia errônea sobre a finalidade profilática e contraceptiva, as dificuldades para a aquisição (SHERRIS et al., 1983; GIR et al., 1994).

A eficácia do condom como método de barreira contra agentes causadores de DST está comprovada. Mas, ao se falar no uso do condom, deve-se ressaltar que ele propicia o sexo seguro se for de qualidade comprovada e desde que utilizado devidamente em todo e qualquer tipo de relação.

O comportamento de risco do homem expõe a mulher ao risco de infecção. Em muitos casos, a mulher torna-se vulnerável pelo comportamento do seu parceiro. Assumir um papel crítico e ativo nas relações interpessoais é uma necessidade para a mulher. Ao desenvolver estas capacidades, a auto-confiança, a auto-estima, a assertividade e o respeito humano mútuo, determinarão o uso das medidas preventivas e contribuirão para o controle efetivo e consciente da disseminação da doença e melhora na qualidade das suas relações.

\section{O MODELO DE CRENÇAS SOBRE O COMPORTAMENTO SEXUAL DAS MULHERES PORTADORAS DE HIV-1}

A partir da inter-relação entre as categorias desenvolvidas, construímos o Modelo de Crenças, referente ao comportamento sexual de mulheres soropositivas ao HIV-1, que tiveram suas gestações resolvidas no HCFMRP-USP (Figura 1). 
O Modelo de Crenças de ROSENSTOCK (1974) pressupõe 3 grupos de comportamentos para fundamentar o modelo: comportamento na saúde, frente ao sintoma e na doença. O modelo é composto por 4 dimensões básicas: susceptibilidade percebida (os riscos subjetivos de contrair uma doença), seriedade percebida, benefícios percebidos (crença na efetivação da ação) e barreiras percebidas, que são aspectos conflitantes para a prevenção.

Através das categorias, emergiram as quatro dimensões básicas preconizadas por ROSENSTOCK (1974) que são: susceptibilidade percebida para a doença, seriedade percebida da doença, benefícios percebidos da ação preventiva e barreiras percebidas da ação preventiva.

No que se refere à vulnerabilidade percebida sobre a infecção/doença, esta assume um papel crucial nos modelos de comportamento em saúde preventiva. Neste estudo, a subestimação à infecção foi muito expressiva. De acordo com o modelo criado, a vulnerabilidade é compreendida através das categorias: percepção da infecção/doença, papel social e comportamento sexual.

Especificamente ao abordar as probabilidades de ação, percebemos que o comportamento assumido antes do conhecimento do diagnóstico da infecção pelo HIV-I, decorreu de aspectos como: subestimação da importancia da infecção pelo HIV- I, falta de preocupação com as DST em geral, desconhecimento dos fatores de risco de seus parceiros sexuais, falta de preocupação com a promoção da saúde e desconhecimento da condição sorológica dos parceiros sexuais.

Quanto à seriedade percebida, entendemos que é de conhecimento geral, que a Aids figura como uma doença fatal, mas esta condição não foi ou é suficiente para as mulheres adotarem medidas preventivas eficazes. Uma vez tendo o diagnóstico estabelecido, as percepções de finitude e de futuro incerto estão presentes entre a maioria das mulheres. No modelo que propomos, a seriedade é percebida através das categorias: percepção da infecção/doença, papel social e comportamento sexual.

Após a confirmação do diagnóstico, certas mulheres desenvolvem estratégias que impedem o sexo seguro, tais como: medos de enfrentar a realidade da infecção e da revelação do diagnóstico aos outros, situações discriminatórias, falta de solidariedade, fragilidade emocional, atribuições negativas ao uso do condom, submissão ao parceiro sexual, falta de assertividade sobre o uso do condom, subestimação das consequências da infecção pelo HIV-1, passividade sobre o seu presente e futuro, percepção de morte próxima, atribuição de cura pela fé religiosa. Essas estratégias foram apreendidas em todas as cinco categorias apresentadas. 


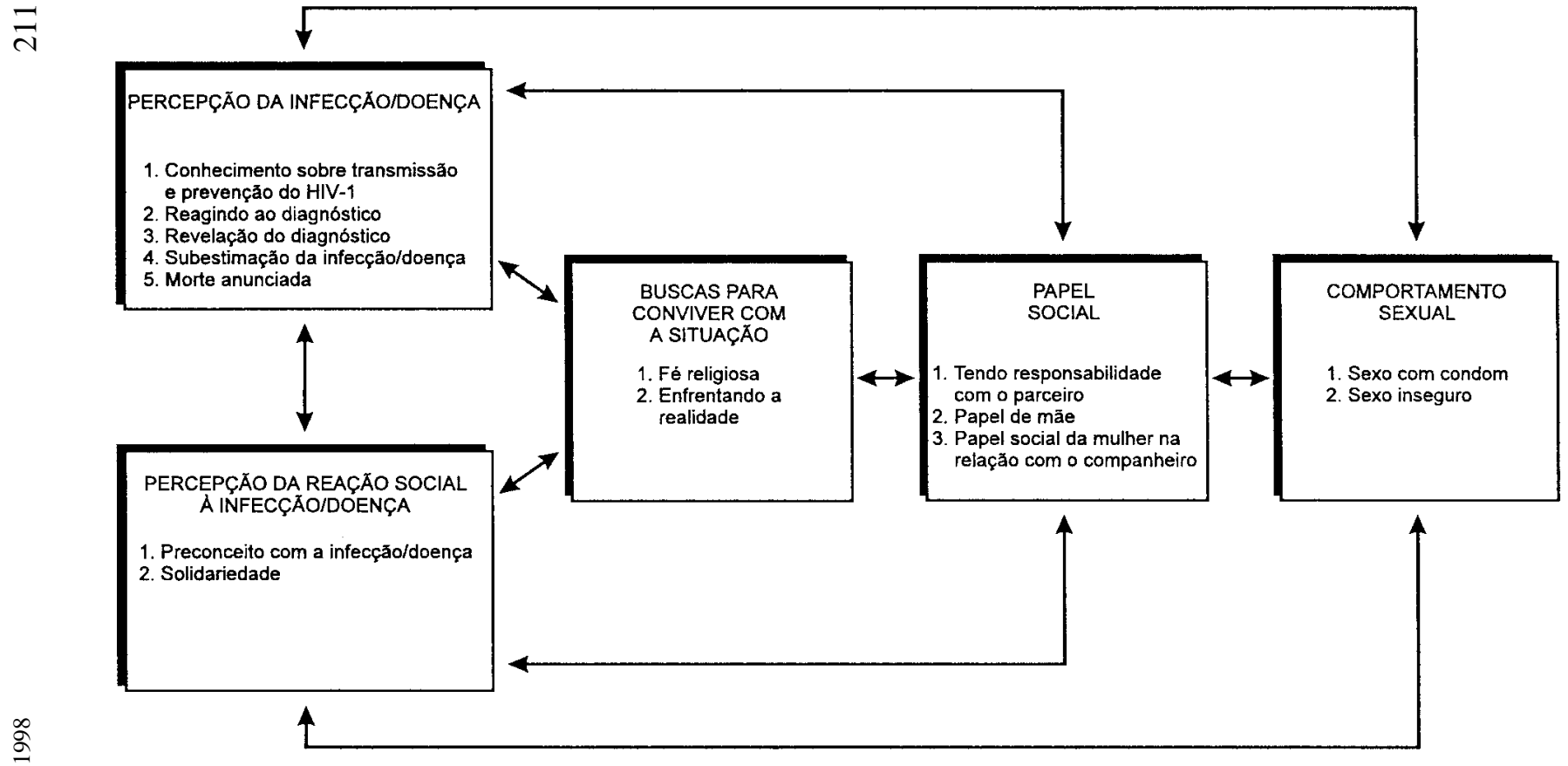

Figura 1 - "Modelo de crenças sobre o comportamento sexual de mulheres soropositivas ao HIV-1 (adaptado de ROSENSTOCK, 1974). 
Como fatores que contribuem para o comportamento sexual seguro, entendidos como benefícios percebidos, algumas informantes apontam o uso sistemático de condom, rompimento de bloqueios sobre os preconceitos, orientações e apoio recebidos dos profissionais da saúde, emprego de medidas que contribuem para uma condição imunológica adequada tais como: alimentação, sono, repouso, afiliação religiosa, evitar fumo, bebidas alcóolicas, drogas ilícitas e re-exposições ao HIV-1.

Os benefícios estão representados, principalmente, através das categorias: percepção da reação social à infecção/doença, buscas para conviver com a situação, papel social e comportamento sexual.

$\mathrm{Na}$ literatura, encontramos resultados semelhantes aos deste estudo. No trabalho de PINEL (1992), os resultados são concordantes no que diz respeito: à manutenção dá atividade sexual após a infecção, ao nível de informação sobre a doença e ao aspecto da possibilidade da contracepção não ter sido um critério suficiente para determinar o comportamento preventivo, a maternidade não foi descartada mesmo diante do resultado soropositivo para a infeccção, a depressão e a falta de apoio emocional que constituem aspectos importantes para determinar as atitudes inadequadas sobre o sexo preventivo e a possibilidade da gestação. No estudo de HANAN (1994), os significados relacionaram-se com as dimensões da discriminação social, da percepção de cura e da morte. PEREIRA (1997) descreveu sobre os fatores das polaridades do bem a do mal, como a sexualidade e a Aids ligada ao mal. A culpa e a auto-punição são reveladas pelas mulheres, além da degeneração da qualidade de vida pelas perdas das condições financeiras, da capacidade física, da desmotivação pela vida. Aponta ainda, a discriminação social, a vergonha dos outros, o isolamento social, a percepção da fatalidade da doença. O ser mãe com Aids, dentro do contexto sócio-cultural, constitue uma condição geradora de conflitos, medos e ansiedades. $\mathrm{O}$ enfrentamento da situação ocorre através das estratégias defensivas de fuga, projeção, negação, compreensão, onipotência.

OS resultados deste estudo mostram a necessidade de intervenção por parte de todos os membros da equipe de saúde que se relacionam com as informantes, por exemplo, quanto as decisões delas de querer ser mãe, sabendo da sua soropositividade à infecção. Esta perspectiva transcende as questões clínicas e pode ocorrer principalmente pela subestimação da infecção. Tal situação impõe a equipe multiprofissional a concentração de esforços, com finalidades e objetivos comuns, visando a trabalhar as questões clínicas e as de ordem psicossociais. 
A pandemia pelo HIV-1 alertou a humanidade para uma série de questões. Aos profissionais de saúde apontou atitudes a serem revisadas, além da constatação da limitação do conhecimento referente à compreensão do comportamento sexual humano.

A sexualidade é um conceito que transcende a reprodução e busca pelo prazer sexual, ela engloba a necessidade de amor e bem estar. Inclui o conhecer-se, enquanto indivíduo, com gênero masculino ou feminino, e as reações e sentimentos resultantes da interação com o outro.

LOPES (1993) ao mencionar as colocações do psicanalista italiano Dacquino, destaca que "a genitalidade é uma função dos órgãos genitnis, um fenômeno fisiológico para satisfazer o instinto. Existe também sem participação da relação, sem uma união afetiva. Entretanto, a sexualidade tem uma dimensão tipicamente pessoal e humana. Claro que também compreende a genitalidade, porém, a supera e a transcende, chegando a um contexto muito mais rico de valores. Esta sobrepõe-se aos limites do impulso genital, que não é mais que um dos muitos elementos de tema relação sexual, em que intervêm a afetividade, a fantasia, a emoção e a comunicação" (pág. 160).

Hoje, os papéis que a mulher desempenha na sociedade mudaram e para ambos os cônjuges, o exercício da sexualidade, com prazer, não é tido como um ato imoral, e para muitos, não é nem indicativo de amor.

Infelizmente, a evolução do comportamento sexual entre as pessoas não se processa de maneira homogênea e isto conduz a sexualidade humana a ser assunto que, às vésperas do século XXI, ainda se reviste de contradições, tabus, desinformações e ignorância, a ponto de muitas pessoas considerarem este tema exclusivo para adultos e criticarem negativamente as iniciativas da educação sexual. Percebe-se ainda, mulheres submissas e passivas no contexto da dimensão sexual com o seu parceiro, deixando de discutir sobre a vida sexual a dois e tampouco impor comportamentos seguros para evitar contrair agentes causadores de doenças transmitidas por via sexual.

A repressão sexual é uma característica que permeia o tempo, os fatos e os povos da história, projetando-se sobretudo através da ausência ou negligência na educação sexual dos indivíduos.

A Aids explodiu no planeta em decorrência da revolução sexual, onde a busca pelo prazer inconseqüente constituía a meta prioritária das pessoas. Por outro lado, a Aids traz a público, o que os estudiosos pioneiros da sexualidade já haviam detectado: a sexualidade humana é muito mais diversa e complexa do que aquilo que é normatizado, pensado, falado, mostrado. A Aids tem uma dimensão sexual oculta, desconhecida e repudiada. 
Ademais, as características e os resultados das pesquisas sobre ela mostram que o profissional de saúde não pode genitalizar suas ações em saúde, pois. para prestar assistência sexual-humanística, o profissional precisa ter competência que extrapole o simples dizer "use camisinha" e transcenda a genitalidade.

\section{CONSIDERAÇÕES FINAIS}

A análise dos dados permitiu-nos averiguar que há mulheres portadoras do HIV-1 desempenhando comportamento sexual inseguro devido a vários aspectos que foram associados a um modelo de crenças. $\mathrm{O}$ modelo é fundamentado nas de cinco categorias identificadas, que emergiram das falas das pacientes, nas quais se apreende significados e dimensões, validadas por elas.

Os resultados obtidos neste estudo trazem uma contribuição importante para a compreensão das atitudes das mulheres portadoras de HIV-1. Ademais, eles mostram a necessidade da intervenção bio-psico-sexual, pelos profissionais de saúde.

Nas fases iniciais da infecção, o indivíduo em geral, mantém seu emprego, suas relações na família, seus amigos. Ao ter os sintomas instalados e o desenvolvimento da doença, ou quando o tratamento profilático é ineficaz, a paciente experimenta sentimentos associados à morte, incluindo-se a negação, medos, ambivalências, iras, buscas de significados e de recursos de enferentamento.

A prevenção da infecção pelo HIV é a melhor medida para todos. Algumas ações dependem sobretudo de decisões de autoridades governamentais, municipais, tais como o controle de qualidade em bancos de sangue, distribuição de seringas e agulhas aos usuários de drogas ilícitas, distribuição de condons, diminuição de impostos sobre os preservativos, tornando o seu custo acessível aos compradores.

Entretanto, a prevenção da transmissão sexual, que é a principal via, depende do indivíduo. Reduzir a susceptibilidade aos riscos de infecção pelo HIV1 constitui-se uma das principais metas dos programas de educação em saúde. Trabalhar a vulnerabilidade percebida, sem dúvida significa trabalhar um ponto crucial do comportamento em saúde preventiva.

O enfermeiro é capaz de identificar os aspectos biopsicosociais que afetam o exercício da sexualidade ao longo do ciclo vital, as consequiências da doença e as privações psicológicas e sócio-culturais da função sexual. 
Embora o enfermeiro não possa atuar como terapeuta sexual, ele pode avaliar os problemas sexuais da mesma maneira que avalia outras necessidades, identificar diagnósticos de enfermagem, educar e intervir.

A ação educativa sobre sexualidade logicamente não se reduz à simples instrução dos aspectos anatõmicos a fisiológicos da sexualidade. É preciso compreender os fatores que e influenciam, nas diversas fases da resposta sexual humana, e que deve, acima de tudo, compreender sexualidade como algo que transcende o ato sexual.

O profissional que se propõe a assistir o indivíduo enquanto ser sexuado, deve buscar subsídios para instrumentalizar-se e somar à competência técnica, ética e profissional, a valorização dos atributos mínimos ao homem, ou seja, o respeito ao próximo, o amor, a humanização.

\section{REFERÊNCIAS BIBLIOGRÁFICAS}

1. BARDIN, L. Análise de conteúdo. São Paulo: Edições 70 Persona, 1977.

2. BRASIL. Ministério da Saúde. Aids. Bol. Epidemiol., v. 10, n. 3, Semana Epidemiológica, 23/97 a 25/97, junho a agosto de 1996/1997.

3. CAPALDINI, L. HIV disease: psychosocial issues and psychiatric complication. In: SANDS, M. A.; VOLBERDING, P. A. The medical management of Aids. 5 $^{\text {a }}$ ed. Philadelphia: Saunders, 1997. cap. 15, pp. 217-237.

4. CLUMECK, N.; TAELMAN, H.; HERMANS, P.; PIOT, P.; SCHOUMACHER, M.; DE WIT, S. A cluster of HIV infection among heterosexual people without apparent risk factors. N. Engl. J. Med., v. 321, n. 21, pp. 1460-1462, 1989.

5. DUARTE, G. Covtribuição ao estudo da infecção da imunodeficiência humana durante o ciclo gravídico-puerperal. São Paulo: 1993, 104p. Tese (Livre Docência). Faculdade de Medicina, Universidade de São Paulo.

6. GIR, E.; MORIYA, T. M.; FIGUEIREDO, M. A. C. Práticas sexuais e a infecção pelo virus da imunodeficiência humana. Goiânia, AB, 1994.

7. GIR, E. A sexualidade e a mulher portadora do HIV-1. Tese Livre Docência. USP/Escola de Enfermagem de Ribeirão Preto - USP, 1997. 201 p.

8. HANAN, J. A percepção social da Aids: raízes do preconceito e da discriminação. Rio de Janeiro: Revinter, 1994.

9. HOCKE. C.; MORLAT, P.; CHENE, G. Prospective cohort study of the effect of pregnancy on the progression of human immunodeficiency virus infection. Obstet. Gynecol., v. 86, n. 6, pp. 886-891, 1995.

10. HOLMBERG, S. D. Risk factors for sexual transmission of human immunodeficiency virus. In DE VITA, V. JR.; HELLMAN, S.; ROSENBERG, S. A. Aids: etiology, diagnosis, treatment and prevention. $4^{a}$ ed. Philadelphia: Lippincott-Raven, 1997. cap. 29.1, pp. 569-575. 
11. JOFFE, H. "Eu não", "O meu grupo não": representações sociais transculturais da Aids. In JOVCHELOVITCH, S.; GUARESCHI, P. (org.). Textos em representações sociais. $2^{a}$ ed., Petrópolis: Cortez, 1995, cap. 9, pp. 297-322.

12. KNAUTH, D. R. Um problema de família: a percepção da aids entre mulheres soropositivas. In LEAL, O. F. Corpo e significado: ensaio de antropologia social. Porto Alegre: Editora da Universidade/UFRGS,1995. pp. 379-390.

13. LOPES. G. Sexualidade humana. 2a ed., São Paulo: MEDSI, 1993.

14. MERTENS, T.; PIOT, P. Global aspects of Human Immunodeficiency virus Epidemiology: general considerations. In DE VITA, V.Jr.; HELLMAN, S.; ROSENBERG, S. A. Aids: etiology, diagnosis, treatment and prevention. $4^{\mathrm{a}}$ ed. Philadelphia: Lippincott-Raven, 1997. cap. 6, pp. 103-118.

15. OSMOND, D. Transmission of HIV in body fluids. In COHEN, P. T.; SANDE, M. A.; VOLBERDING, P. A. (ed.). The Aids knowledge base. Waltham: Edwards Brothers, 1990, cap. 1.2.1, pp. 1.2.1-1 a 3.

16. PEREIRA, M. L. D. Ser mãe e estar com Aids: o revivecimento do pecado original. São Paulo: 1997. 66p. Dissertação (Mestrado). Escola de Enfermagem, Universidade de São Paulo.

17. PINEL, A. C. Sexual and reproductive behavior of HIV positive women. In INTERNATIONAL CONFERENCE ON Aids/III STD WORLD CONGRESS AMSTERDAN. Netherlands: 19-24 July, 1992. Poster Abstracts, v. 2, p. C381 Abstracts $n^{\circ}$ PoC4831.

18. REED, P. Spirituality and well being in terminally ill hospitalized adults. Res. Nurs. Health, v. 10, n. 5, pp. 335-344, 1987.

19. ROSENSTOCK, I. M. The health belief model and preventive health behavior. Health Educ. Monographs, v. 2, n. 4, pp. 354-387, 1974.

20. SHERRIS, J. D.; LEWISON, D.; FOX, G. Atualização sobre condons: produtos, proteção e promoção. Popul. Rep., n. 6, pp. H.1-H.40, 1983./Série H/.

21. van VLIET, A.; van ROOSMALEN, J. Worldwide prevention of vertical human immunodeficiency virus (HIV) transmission. Obstet. Gynecol. Survey, v. 52, n. 5, pp. 301-309, 1997.

22. WORLD HEALTH ORGANIZATION. WHO. Statistics from the World Health Organization. Aids, v. 9, n. 11, pp. 1297-1298, 1995. 